\title{
Ferulic Acid Prevents Angiogenesis Through Cyclooxygenase-2 and Vascular Endothelial Growth Factor in the Chick Embryo Chorioallantoic Membrane Model
}

\author{
Ferulik Asitin Tavuk Embriyo Koriyoallantoik Membran Modelinde \\ Siklooksijenaz 2 ve Vasküler Endotel Büyüme Faktörü Üzerinden \\ Anjiyojenezi Önlemesi
}

\author{
(D) Juni EKOWATI*, (D) Iwan Sahrial HAMID², (D) Nuzul Wahyuning DIYAH ${ }^{1}$, (D) Siswandono SISWANDONO1 \\ 1Airlangga University Faculty of Pharmacy, Department of Pharmaceutical Chemistry, Surabaya, Indonesia \\ ${ }^{2}$ Airlangga University Faculty of Veterinary Medicine, Department of Basic Veterinary Medicine, Surabaya, Indonesia
}

\begin{abstract}
Objectives: This study was designed to verify the antiangiogenic activity of ferulic acid (FA) and its potency to inhibit cyclooxygenase-2 (COX-2) and vascular endothelial growth factor (VEGF) expression in the chorioallantoic membrane (CAM) model. Moreover, we verified its mechanism of action by docking the molecule on COX-2, tyrosine kinase, and VEGF-2 proteins in silico.

Materials and Methods: An antiangiogenesis assay of FA at doses of 30, 60, and $90 \mu \mathrm{g}$ was performed using the CAM of chicken eggs that were 9 days old and stimulated by $60 \mathrm{ng}$ of basic fibroblast growth factor. Celecoxib $(60 \mu \mathrm{g})$ was used as the reference drug. The inhibitory activity on VEGF and COX-2 expression was determined by immunohistochemistry assay. Molecular docking of FA was accomplished by Molegro Virtual Docker program ver. 5.5 on COX-2 enzyme (PDB ID 1CX2), tyrosine kinase receptor (PDB ID 1XKK), and VEGF-2 receptor (PDB ID 4ASD).

Results: FA at doses of 30,60 , and $90 \mu \mathrm{g}$ significantly prevented angiogenesis in the CAM model, which was represented as inhibitory activity against endothelial cells of blood vessels (42.6-70.7\%) and neovascularization (43.0-86.6\%). The inhibitory activity of FA against VEGF expression was stronger than its action on COX-2 expression. Molecular docking on VEGF-2 receptor resulted in an RS value of FA of -73.844 kcal/mol and for celecoxib it was $-94.557 \mathrm{kcal} / \mathrm{mol}$. The RS value on tyrosine kinase of FA was $-84.954 \mathrm{kcal} / \mathrm{mol}$, while on celecoxib it was $-93.163 \mathrm{kcal} / \mathrm{mol}$. Docking on COX-2 receptor gave an RS value of FA of $-73.416 \mathrm{kcal} / \mathrm{mol}$, while for celecoxib it was $-118.107 \mathrm{kcal} / \mathrm{mol}$.

Conclusion: Reductions in VEGF-2 and COX-2 expression due to treatment with FA at the dose range 30-90 $\mu$ g appeared to be related to angiogenesis inhibition, which was shown by two parameters, namely inhibition of neovascularization and endothelial cell growth in blood vessels. It was concluded that FA is a promising antiangiogenic therapeutic agent especially at the early stage, and this activity can arise from inhibitory action on COX-2 and VEGF-2 proteins.
\end{abstract}

Key words: Ferulic acid, COX-2, VEGF, tyrosine kinase, angiogenesis, chorioallantoic membrane

öz

Amaç: Bu çalışma ferulik asidin (FA)'nın koriyoallantoik membran (CAM) modelinde antianjiyojenik aktivitesini ve siklooksijenaz-2 (COX-2) ve vasküler endotel büyüme faktörünü (VEGF) inhibe etme potensinin doğrulamak üzere tasarlanmıştır.

Gereç ve Yöntemler: FA'nın antianjiyojenik testi dokuz günlük olan ve 3 ng bazik fibroblast faktörü ile stimüle edilen tavuk yumurtalarının CAM'ına

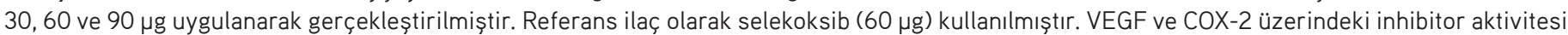
immünohistokimya yöntemi ile gerçekleştirilmiștir. FA'nın moleküler kenetlenmesi Molegro Virtual Docker program ver. 5,5 ile COX-2 enzimi (PDB ID 1CX2), tirozin kinaz reseptörü (PDB ID 1XKK) ve VEGF-2 reseptörü (PDB ID 4ASD) üzerinde gerçekleștirilmiștir.

*Correspondence: E-mail: juni-e@ff.unair.ac.id, Phone: +081332041503 ORCID-ID: orcid.org/0000-0002-4402-2039

Received: 04.12.2018, Accepted: 04.04.2019

๑Turk J Pharm Sci, Published by Galenos Publishing House. 
Bulgular: FA 30, 60 ve $90 \mu \mathrm{g}$ dozlarsa CAM modelinde belirgin bir şekilde anjiyojenezi önlemiştir ve kan damarlarının endotel hücrelerine karşı inhibitor aktivite $(\% 42,6-\% 70,7)$ ve neovaskülarizayon (\%43,0-\%86,6) göstermiştir. FA'nın VEGF eksptresyonuna karşı inhibitor aktivitesi COX-2 ekspresyonuna karşı olan etkisinden daha güçlü bulunmuştur. FA için VEGF-2 reseptörüne moleküler kenetlenme RS değeri -73,844 kcal/mol ve selekoksib için -94,557 kcal/mol'dür. FA'nın tirozin kinaz üzerine RS değeri -84,954 kcal/mol iken selekoksib üzerine -93,163 kcal/mol'dür. FA'nın COX-2 reseptörü üzerine kenetlenmesinde RS değeri $-73,416 \mathrm{kcal} / \mathrm{mol}$ iken, selekoksib üzerine kenetlenme değeri $-118,107 \mathrm{kcal} / \mathrm{mol}$ 'dür.

Sonuç: $30-90 \mu \mathrm{g}$ aralığında FA uygulaması ile VEGF-2 ve COX-2 ekspresyonlarında görülen azalmalar anjiyojenez inhibisyonuna ilişkili olarak görülmektedir ve bu 2 parametre (neovaskülarizasyon ve kan damarlarında endotel hücre büyümesinin inhibisyonu) ile gösterilmiștir. Sonuç olarak FA'nın özellikle erken evrede ümit vaat eden antianjiyojenik terapötik bir ajan olduğu söylenebilir ve bu aktivite COX-2 ve VEGF-2 proteinleri üzerindeki inhibitör etkisinden kaynaklanıyor olabilir.

Anahtar kelimeler: Ferulik asit, COX-2, VEGF, tirozin kinaz, anjiyojenez, koryoallantoik membran

\section{INTRODUCTION}

The progression of cancer cells depends heavily on angiogenesis, the formation of new blood vessels that supply oxygen and food required for the tumor's cell proliferation and metastasis progression.,2 The development of cancer cells is induced by angiogenesis, which is activated by some growth factors such as vascular endothelial growth factor receptor (VEGFR). Two important growth factor receptors that influence angiogenesis are tyrosine kinase receptor (TKR) and VEGFR-2., ${ }^{1,3}$

The VEGF signaling pathway is a strategic target for angiogenesis inhibitors. ${ }^{4,5}$ However, there are some clinical problems involving angiogenesis inhibitors in patients (i.e. thromboembolic disorders, intracranial hemorrhage, and bowel perforation). ${ }^{6}$ Other problems are the occurrence of toxicities such as bleeding, fatigue, hypertension, and perforation of the gastrointestinal tract. ${ }^{7.8}$ Therefore, the study of a new antiangiogenic substance that is relatively safe in its pharmaceutical dosage form is an important step in cancer treatment.

Ferulic acid (FA) [3-(4-hydroxy-3-methoxyphenyl)-2propenoic acid] (Figure 1) is a phenolic acid compound that shows antioxidant 9,10 and cytotoxic activities in many cancer cell lines. ${ }^{11,12}$ Wang et al..$^{13}$ reported that FA could inhibit the proliferation and induced apoptosis of osteosarcoma cells via the PI3K/Akt pathway. FA also had anti-inflammatory activity and inhibited cyclooxygenase-2 (COX-2) enzyme, ${ }^{14}$ which were related to angiogenesis. ${ }^{2,15}$ Koki and Masferrer ${ }^{16}$ reported that COX-2 expression increased during the tumorigenesis process and the intensity of its expression was in line with the degree of carcinogenesis. Wu et al. ${ }^{17}$ reported that the biosynthesis of PG catalyzed by COX-2 could stimulate the VEGF expression in tumor cells and acted as a positive feedback loop between tumor cells and endothelial cells.

In an effort to improve FA as a drug candidate for cancer chemoprevention, we studied its antiangiogenic activity and inhibitory activity against COX-2 and VEGF expression in the chicken egg chorioallantoic membrane (CAM) model. The CAM assay is a robust and applicable technique to assess a potential drug candidate. The assay has been commonly used to study angiogenesis and tumor invasion in various types of cancer.18,19 To verify FA's mechanism in the inhibition of angiogenesis, we conducted molecular docking on COX-2 enzyme, tyrosine kinase, and VEGF-2 receptors.

\section{MATERIALS AND METHODS}

\section{Materials}

Commercially available materials were used as obtained. FA, Tris- $\mathrm{HCl}$, and basic fibroblast growth factor (bFGF) were purchased from Sigma-Aldrich (St Louis, MO, USA). The chicken eggs were collected from PUSVETMA Surabaya, Indonesia.

\section{Chorioallantoic membrane assay}

Twenty-five 9-day-old chicken eggs were incubated at $37^{\circ} \mathrm{C}$ (60$70 \%$ humidity) for 1 day. All of the treatment groups of CAMs were induced by bFGF at a concentration of $1 \mathrm{ng} / \mu \mathrm{L}$ in Tris- $\mathrm{HCl}$ solution of $\mathrm{pH}$ 7.5. The eggs were divided into five groups; each group consisted of six eggs. Three groups were treated with FA at doses of 30,60 , and $90 \mu \mathrm{g}$; the positive control group was treated with celecoxib $(60 \mu \mathrm{g})$ and one group received no treatment, which was set as the negative control. The egg was perforated to make a hole $1 \mathrm{~cm}^{2}$ in diameter to remove the air. Sterile Whatman filter-paper disks $5 \mathrm{~mm}$ in diameter with tested compound and bFGF or bFGF alone were dropped into the hole and then were impregnated into the CAM of each embryo. The hole was covered and the egg returned to incubation at $37^{\circ} \mathrm{C}$ (60\% humidity) for $72 \mathrm{~h}$. After incubation, the upper eggshell was opened and the presence of neovascularization from the main blood vessels onto the paper disks was recorded. In addition, we also collected the blood vessels of the CAM in formalin buffer and carried out microscopic observations of the histopathologic slide of the CAM using hematoxylin and eosin staining. To confirm the antiangiogenic activity, this CAM assay was achieved with certain alteration as explained before. ${ }^{18,20}$ The growth of the endothelial cells in the neovascular capillaries was exposed in CAM cross-sections by an inverted phase contrast microscope, a Nikon H600L. The number of endothelial cells in five graphical fields were calculated, whereas each slide was observed at 400x amplification and compared with the positive or negative control groups for the following analysis.

\section{Antibodies}

Rabbit polyclonal anti-human COX-2 and VEGF antibodies were obtained from Thermo Scientific ${ }^{T M}$ Lab Vision $^{T M}$ (St Louis, MO, USA).

\section{Immunohistochemical assay}

The slides for the immunohistochemical assay were prepared at the Laboratory of Anatomical Pathology, Dr. Sardjito Hospital, Yogyakarta, Indonesia. Paraffin blocks of the CAM 
containing blood vessels were cut 3-4 $\mu \mathrm{m}$ thick and placed on the poly-lysine slide, and then they were incubated overnight at $45^{\circ} \mathrm{C}$. The next step of VEGF or COX-2 staining for the immunohistochemical assay was carried out as reported in previous research.18,19 In the present study, we used Mayer's hematoxylin for counterstaining. Tris-EDTA solution at $\mathrm{pH} 9$ was used in the retrieval step of VEGF staining for 15-20 min, whereas $\mathrm{pH} 6$ citrate buffer was used for retrieval of COX-2 staining for 15-20 min. The slides were divided into six groups. One group consisted of slides of CAM expressing COX-2 protein, which was used as the positive control; three groups contained slides of FA at doses of 30,60 , and $90 \mu \mathrm{g}$, one group contained slides of celecoxib at a dose of $60 \mu \mathrm{g}$, which was used as the reference drug; and one group was used as a negative control group. The microscopic observation of VEGF expression and COX-2 expression was continued by counting the visible brown cells in five fields for a minimum of 100 cells. This assay was approved by the Ethical Commission of Airlangga University, but it did not involve human participants.

\section{Statistical analysis}

The data obtained were subjected to ANOVA and a OneWay Fisher exact test at $95 \%$ level of confidence. If there was significant variance among each group, the analysis was continued with Duncan's multiple range test. Statistical significant was set at $p<0.05$. All statistical analyses were presented using IBM SPSS 21.

\section{Molecular docking equipment}

Hardware: Laptop ASUS AMD A8 Vision with CPU $Q 1.9 \mathrm{GHz}, 4$ GB of RAM.

Software: CS ChemDraw Ultra version 12.00 (Cambridge Soft) was utilized to create the three-dimensional structure (3D) of FA, which was then subjected to energy minimization by MMFF94 method and the 3D structure was saved in SYBYLMol2 format (*.Mol2). Molegro Virtual Docker (MVD) version 5.5 (CLC Bio) was employed as a docking program in this research. The 3D structures of COX-2, TKR, and VEGF-2 proteins were downloaded from the Internet (http://www.rcsb.org/pdb/home/ home.do)

\section{In silico assay}

The 3D structures of the three proteins, which were obtained from a protein data bank (PDB), were: 1) 1XKK, which was TKR containing $\mathrm{N}$-(3-chloro-4-[(3-fluorobenzyl)oxy]phenyl\}6-[4-quinazo-linamine) (code FMM-901) as reference ligand, 2) 4ASD, which was VEGFR-2 containing sorafenib (BAX 43-9006) as reference ligand, and (3) 1CX2, which was COX2 containing [4-(5-(4-bromophenyl)-3-(trifluoro-methyl)-1Hpyrazole-1yl)benzenesulfonamide) (SC58)] as reference ligand. Ligand-protein interactions were prepared by FA molecule MVD version software 5.5. Docking of the FA molecule into each of the $3 \mathrm{D}$ structures of proteins was performed as described in our previous study. ${ }^{20}$ The best docking results can be observed by relating the structure of the docked FA molecule to the crystal structure of the reference ligand at the binding site. The docking results were presented as a rerank score (RS), which was the total free energy of the ligand-protein interaction. The lowest energy indicated the best pose of binding between the functional group of ligand and amino acid residues of the proteins. The ligand-protein complexes of the lowest score (RS) were used for further visual inspection. The validation of the docking result was performed by redocking the reference ligand into the same cavity in each protein. The redocking result was accepted if the root mean square deviation $<2.0 \AA$.

\section{RESULTS AND DISCUSSION}

\section{Antiangiogenic activity of ferulic acid}

The antiangiogenesis assay is performed on the CAM of the embryonated chicken egg because the membrane is the site of very high vascularization and is easily observable in line with the process of chicken embryo growth. ${ }^{18,21}$ The CAM is a fusion of chorion and allantois of chicken egg membrane formed after 4 days of incubation. ${ }^{18}$ The formation of new blood vessels is derived from the capillaries that arise from the blood vessels.

Angiogenesis in the CAM model through macroscopic observations of new blood vessels induced by bFGF was significantly inhibited $(p<0.05)$ by FA at doses of 30,60 , and $90 \mu \mathrm{g}$. The results are represented by inhibition of neovascularization (Figure 2).

Neovascularization is inseparable from the preceding mechanism of growth and the formation of new endothelial cells, whereas one of the angiogenesis stages is endothelial cell migration. ${ }^{22}$ At this stage, the capillary walls of the blood vessels continue their growth into the lumen of other blood vessels. There are four phases of migration: the growth of two opposite capillary walls, the joining of regulated endothelial cells and bending of the bilayer facilitate growth factors so the cells enter the lumen, and the center of angiogenesis is

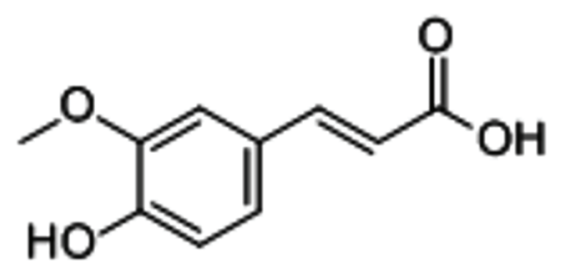

Figure 1. Ferulic acid

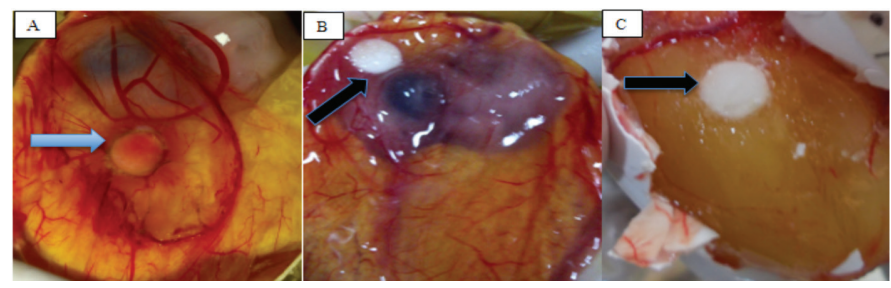

Figure 2. A) Capillary of neovascularization of CAM induced by $60 \mu \mathrm{g}$ of bFGF (blue arrow) in control positive group, B) capillary of neovascularization of CAM induced by $60 \mathrm{ng}$ of bFGF and treated with $60 \mu \mathrm{g}$ of celecoxib (black arrow), C) capillary of neovascularization of CAM induced by $60 \mu \mathrm{g}$ of bFGF and treated with $60 \mu \mathrm{g}$ of FA (black arrow)

CAM: Chorioallantoic membrane, bFGF: Basic fibroblast growth factor, FA: Ferulic acid 
formed between the new blood vessels filled by pericytes and myofibroblasts. The center of angiogenesis is the appearance of smooth muscle fibers that complement the formation of new blood vessels with the development of hematopoiesis as early vascularization.

Figure 2 shows several capillary blood vessels progressing into the impregnated disk of the group without treatment. After treatment with FA and celecoxib, there was a decrease in the number of new blood vessels around the disk on the CAM and endothelial cells of blood vessels. The percentages of inhibition of neovascularization and endothelial cell growth of blood vessels are shown in Table 1.

Based on the statistical analysis by one-way ANOVA, followed by Duncan's multiple range test, it is known that there is no significant difference in potency of the inhibition of neovascularization between celecoxib at $60 \mu \mathrm{g}$ dose and FA at $60-90 \mu \mathrm{g}$ dose $(p<0.05)$. However, the potency of FA at 30 $\mu \mathrm{g}$ is smaller than that of FA at $60-90 \mu \mathrm{g}$, whereas the potency of $F A$ at $90 \mu \mathrm{g}$ dose to inhibit endothelial cells of blood vessels is stronger than that of FA at $30-60 \mu \mathrm{g}$ dose. No significant differences were seen in the potency of inhibition of endothelial cells of blood vessels between FA at $90 \mu \mathrm{g}$ dose and celecoxib at $60 \mu \mathrm{g}$ dose $(\mathrm{p}<0.05)$. As a reference drug, celecoxib $(60 \mu \mathrm{g})$ provided $83 \%$ new blood vessel growth inhibition in the CAM model.

\section{Ferulic acid inhibited VEGF and COX-2 expression}

The microscopic image of VEGF expression in the endothelial cells of the new blood vessels belonging to the positive control group is dominated by the presence of a brown color. It is in sharp contrast to an image from the negative control group, which displays a dominant blue color in the endothelial cell cytoplasm. The brown color in the cytoplasm indicates that VEGF expression of the endothelial cells treated by FA decreases with increasing dose of the substance from $30 \mu \mathrm{g}$ to $90 \mu \mathrm{g}$. The microscopic observation results of VEGF expression in each treatment group are presented in Figure 3.

The microscopic observation results of COX-2 expression in each treatment group are presented in Figure 4. All data of the treatment group are presented in Table 2 and analyzed by SPSS version 21.0 for Windows.

Analysis of percentage inhibition of VEGF expression by FA using the one-sample Kolmogorov-Smirnov test for normality showed probability of $p=0.398$, whereas percentage inhibition of COX-2 expression with the one-sample Kolmogorov-Smirnov test showed probability of $p=0.458$. This means the data are normally distributed because $p$ is greater than 0.05 ( $p>0.05$ ). Based on statistical analysis by One-Way ANOVA, continued
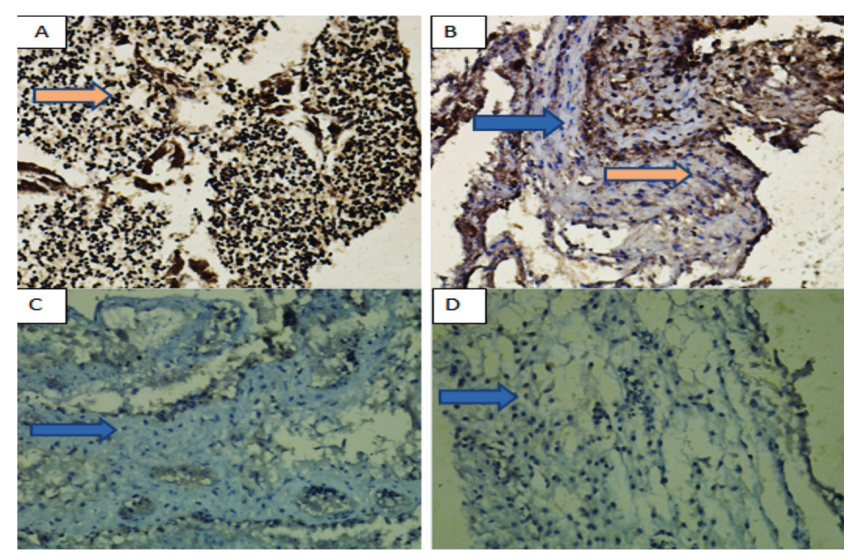

Figure 3. VEGF expression within endothelial cells of blood vessels of the CAM, 400 times magnification: A) positive control group (blank treatment with $60 \mu \mathrm{g}$ of bFGF), B) group of $60 \mu \mathrm{g}$ celecoxib treatment, C) group of 60 $\mu \mathrm{g} F \mathrm{~A}$ treatment, D) group of $90 \mu \mathrm{g} F \mathrm{~F}$ treatment. Arrows indicate there is VEGF expression

VEGF: Vascular endothelial growth factor, CAM: Chorioallantoic membrane, bFGF: Basic fibroblast growth factor, FA: Ferulic acid
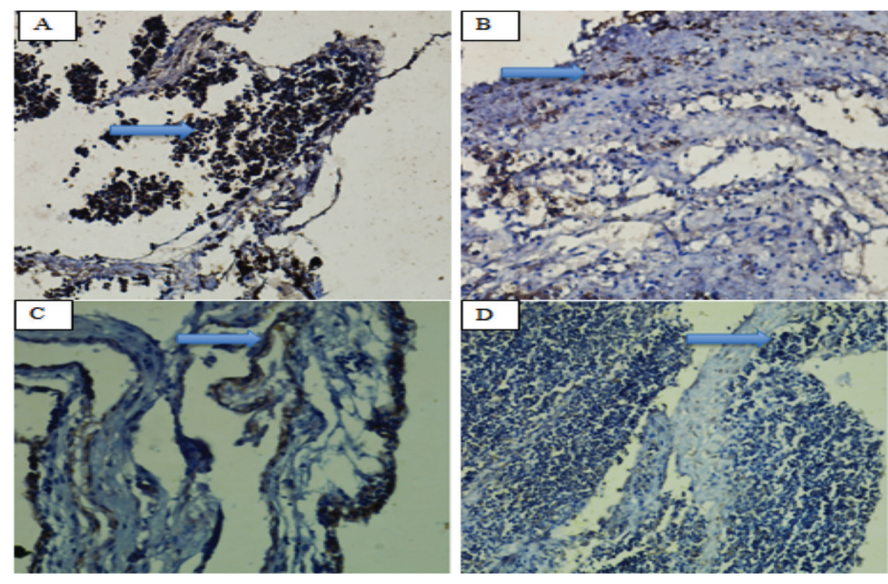

Figure 4. COX-2 expression within endothelial cells of blood vessels of the CAM, 400 times magnification: A) positive control group (blank treatment with $60 \mu \mathrm{g}$ of bFGF), B) group of $60 \mu \mathrm{g}$ celecoxib treatment, C) group of 60 $\mu \mathrm{g}$ FA treatment, D) group of $90 \mu \mathrm{g}$ FA treatment. Arrows indicate there is COX-2 expression

COX-2: Cyclooxygenase-2, CAM: Chorioallantoic membrane, bFGF: Basic fibroblast growth factor, FA: Ferulic acid

Table 1. Antiangiogenesis activity in the CAM model in each group

\begin{tabular}{lll}
\hline Treatment & $\%$ inhibition of neovascularization & $\%$ inhibition of endothelial cells \\
\hline Celecoxib $60 \mu \mathrm{g}$ & $83.3^{\mathrm{b}} \pm 5.2$ & $79.3^{\mathrm{c}} \pm 2.3$ \\
\hline FA $30 \mu \mathrm{g}$ & $43.0^{\mathrm{a}} \pm 4.6$ & $42.6^{\mathrm{a}} \pm 5.9$ \\
\hline FA $60 \mu \mathrm{g}$ & $83.4^{\mathrm{b}} \pm 7.4$ & $57.3^{\mathrm{b}} \pm 4.3$ \\
\hline FA $90 \mu \mathrm{g}$ & $86.6^{\mathrm{b}} \pm 6.2$ & $70.7^{\mathrm{c}} \pm 3.9$ \\
\hline
\end{tabular}

All values are represented as the mean \pm SE $(n=6)$ and different superscripts in the same column

indicate that there were significant different in each group ( $p<0.05)$

FA: Ferulic acid, CAM: Chorioallantoic membrane, SE: Standard error 
with LSD and Duncan's multiple range tests, it is known that there is no significant difference in the potency of inhibition of VEGF expression between celecoxib at $60 \mu \mathrm{g}$ dose and FA at $60-90 \mu \mathrm{g}$ dose $(p<0.05)$. The potency of FA inhibiting VEGF expression at $30 \mu \mathrm{g}$ to $90 \mu \mathrm{g}$ was dose-dependent. Increasing dose of FA resulted in decreasing VEGF expression of CAM significantly.

Based on the data in Table 2, it is known that giving 30-90 $\mu \mathrm{g}$ of FA decreases VEGF expression in CAM significantly. Reduced VEGF expression due to treatment with FA at 30-90 $\mu$ g doses is in line with angiogenesis inhibition, which is shown by two parameters, namely neovascularization and resistance to endothelial cell growth of blood vessels in the chick embryo CAM.

The main VEGF receptor in endothelial cells is VEGFR-2, which influences developing and adult cells. VEGFR-2 signaling is better recognized than the other VEGF receptors' signaling. Vascular permeability is an essential in vivo consequence of VEGFR-2 activation. Several small-molecular-weight inhibitors of VEGFR-2 kinase activity are employed clinically to block pathological angiogenesis in cancer. ${ }^{13}$

In vitro experiments on capillary endothelial cells showed that VEGF is a powerful stimulator against the occurrence of angiogenesis. This is due to its presence as a growth factor triggering the proliferation and migration of endothelial cells, even the formation of tube formation in a series of capillary vessels. ${ }^{23}$ Inhibition of VEGF can occur in several ways; the first is inhibition at the VEGF receptor through kinase activity that contributes to the delivery of growth signals. The second possibility is inhibition through endothelial cell apoptosis induction, whereas the third may involve the incorporation of hematopoiesis and endothelial progenitor cells, and so VEGF is not capable of triggering vasculogenesis. ${ }^{24}$
According to Di Marco et al. ${ }^{25}$, binding of VEGFR and VEGFspecific ligand occurs in the transmembrane and cytoplasmic domains. VEGF is known as a promoter of angiogenesis and an endogenous regulator of endothelial integrity. Some antiVEGF compounds can cause endothelial dysfunction and decreased angiogenesis.

The COX-2 expression in the CAM also presented a brown color in the cell cytoplasm, which is a ligand-receptor complex of COX-2 detected by anti-COX-2 antibodies that are specifically bound to COX-2 ligand. Based on the data in Table 2, it is known that treatment with 30-90 $\mu$ g of FA can significantly decrease COX-2 expression in the CAM. The inhibitory activity of FA against COX-2 expression is dose-dependent. The inhibitory potency of FA at dose range $30-90 \mu \mathrm{g}$ is significantly different from that of celecoxib at the $60 \mu \mathrm{g}$ dose. In our study, the administration of FA appeared to play an important role in angiogenesis inhibition through decreasing COX-2 expression.

The reduction in COX-2 expression due to treatment with FA at the dose range $30-90 \mu \mathrm{g}$ seems to have been related to angiogenesis inhibition, which is shown by two parameters, namely inhibition of neovascularization and inhibition of endothelial cell growth in blood vessels of chick embryo CAM. Hsu et al. ${ }^{26}$ reported that prostaglandin-E2 (PGE2) stimulates COX-2 expression in LoVo colon cancer cells. The COX2 expression was interrelated with the elevation in the migration ability of those cancer cells. The experimental data suggested that PGE2 can be a potential therapeutic target in colon cancer metastasis. Yao et al. ${ }^{27}$ stated that downregulation of COX-2 could significantly diminish the progression of gastric cancer cells and block the replacement and tube formation of human umbilical vein endothelial cells. The results also indicated that downregulation of COX-2 might inhibit VEGF.

Table 2. Inhibition of VEGF and COX-2 expression in the CAM model in each group

\begin{tabular}{lll} 
Treatment & \% inhibition of VEGF expression & \% inhibition of COX-2 expression \\
\hline Celecoxib $60 \mu \mathrm{g}$ & $72.9 \pm 6.8^{\mathrm{b}}$ & $84.1 \pm 4.2^{\mathrm{c}}$ \\
\hline FA $30 \mu \mathrm{g}$ & $46.7 \pm 8.0^{\mathrm{a}}$ & $49.9 \pm 6.3^{\mathrm{a}}$ \\
\hline FA $60 \mu \mathrm{g}$ & $63.7 \pm 4.9^{\mathrm{b}}$ & $55.0 \pm 4.6^{\mathrm{a}}$ \\
\hline FA $90 \mu \mathrm{g}$ & $73.6 \pm 5.3^{\mathrm{b}}$ & $66.8 \pm 2.8^{\mathrm{b}}$ \\
\hline
\end{tabular}

All values are represented as the mean $\pm S E(n=6)$ and different superscripts in the same column

indicate that there were significant differences in each treatment $(p<0.05)$

VEGF: Vascular endothelial growth factor, COX-2: Cyclooxygenase-2, CAM: Chorioallantoic membrane, FA: Ferulic acid

Table 3. The rerank score, type of bonding interactions, and amino acids involved in the interaction of ligands with VEGFR-2 (PDB ID 4ASD)

\begin{tabular}{|c|c|c|c|c|c|}
\hline Compound & $\begin{array}{l}\text { Rerank score (kcal/ } \\
\mathrm{mol} \text { ) }\end{array}$ & $\begin{array}{l}\text { Number of } \\
\mathrm{H} \text {-bonds }\end{array}$ & Amino acid residue & $\begin{array}{l}\text { Number of } \\
\text { steric interactions }\end{array}$ & Amino acid residue \\
\hline FA & -73.844 & 1 & Glu885 & 6 & $\begin{array}{l}\text { Ala1050, Glu885, } \\
\text { Leu 889, Val } 848\end{array}$ \\
\hline Celecoxib & -94.557 & 2 & $\begin{array}{l}\text { Gln847 } \\
\text { Lys868 }\end{array}$ & 24 & $\begin{array}{l}\text { Asn1033,Cys1045, } \\
\text { Gln847, Glu885, } \\
\text { Lys868, Phe1047, } \\
\text { Val848, Val867, Val914 }\end{array}$ \\
\hline
\end{tabular}

VEGFR-2: Vascular endothelial growth factor receptor-2, FA: Ferulic acid, FA: Ferulic acid, Lys: Lysine, Met: Methionine, Asp: Aspartic Ala: Alanine, Gly: Glutamine, Ser: Serine, Leu: Leucine, Tyr: Tyrosine, Val: Valine, Phe: Phenylalanine 
The COX-2 inhibitor celecoxib ${ }^{28}$ has been reported to inhibit the growth of prostate, gastric, lung, and breast cancer. ${ }^{29,30}$ The induction of bFGF as pro-angiogenic compounds will lead to inflammation associated with the COX-2 activity. ${ }^{31,32}$ As well as celecoxib, FA also inhibited COX-2 enzyme ${ }^{14,30}$ and so it could obstruct bFGF activity as a pro-angiogenic compound.

Based on the inhibitory mechanism of angiogenesis through the inhibition of VEGF expression examined by other researchers in several studies, it is possible that FA inhibits VEGFR-2 through its inhibitory activity on tyrosine kinase and COX-2. This assumption is studied and proven through in silico docking on COX-2, TKR, and VEGFR-2.

\section{Docking study}

The best-docked pose of FA, celecoxib, and BAX ligands in the binding site of VEGFR-2 and the interactions between functional groups of $F A$ and celecoxib with amino acid residues in two-dimensional (2D) structures are shown in Figure 5. The docking scores (RS value), the type of bonding interactions with VEGFR-2, and amino acids involved in their interactions are listed in Table 3.

The best-docked pose of FA, celecoxib, and native ligand in the binding site of tyrosine kinase and their interactions with amino acid residues in $2 \mathrm{D}$ structures are shown in Figure 6 . The RS value, the type of interactions, and amino acids involved in the interaction between ligand and TKR are listed in Table 4.
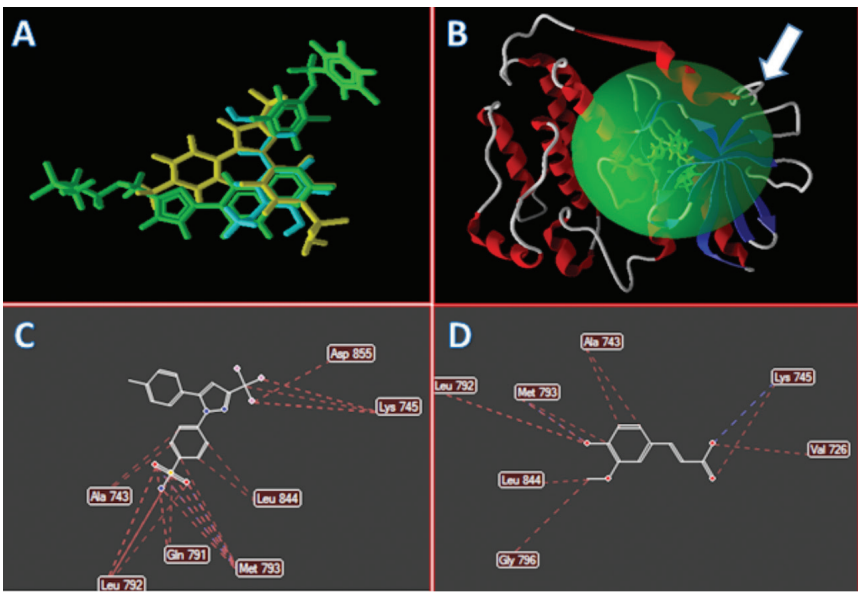

Figure 5. The best docking of FA (yellow)-celecoxib (blue)-BAX (green) ligands $A$ ); the three ligands positioned at the active site (cavity-2) of VEGFR-2 B), interaction of celecoxib with amino acids in cavity-2 of VEGFR-2 C); interaction of FA with amino acids in cavity-2 of VEGFR-2 D) FA: Ferulic acid, VEGFR-2: Vascular endothelial growth factor receptor-2
The ligand of PDB ID 1XKK contains a benzylic group (ArC-), which acts as a pharmacophore in the ligand-receptor interaction complex. The FA compound contains a similar group, which is also expected to be a pharmacophore. Celecoxib, which produces a lower RS value than FA (Table 3), displays more $\mathrm{H}$-bonds and steric interactions with TKR than FA.

The best-docked pose of FA, celecoxib, native ligand in the binding site of COX-2 and their interactions with amino acid residues of each protein in $2 \mathrm{D}$ structures are shown in Figures 5-7. The RS value, the type of bonding interactions with COX2 , and amino acids involved in their interactions are listed in Table 5.

Based on the molecular docking study, the possible interactions can be explained between each compound, i.e. FA and celecoxib, with amino acid residues in each protein enzyme/receptor. The FA-TKR interaction is stronger than FAVEGFR-2, indicating the possibility that FA worked on growth factor receptors, ${ }^{1,31}$ and it is apparent that FA inhibited VEGF expression in the CAM model.

The ligand binding of VEGFR stimulated strong tyrosine phosphorylation and results in an intense angiogenesis response. ${ }^{31}$ Replacement of the native ligand of VEGFR-2 with FA through the interactions of functional groups of FA with the amino acid residue of VEGFR-2 prevented tyrosine phosphorylation and so decreased angiogenesis. ${ }^{32}$

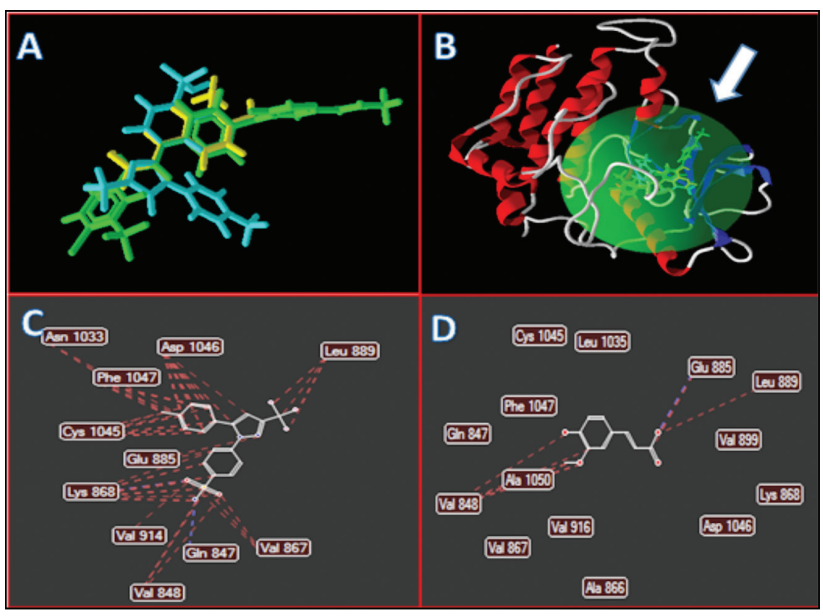

Figure 6. The best docking of FA (yellow)-celecoxib (blue)-FMM (green) A); the three ligands positioned at the active site (cavity-1) of TKR; B), interaction of celecoxib with amino acids of TKR C); interaction of FA with amino acids of TKR D), PDB 1XKK

FA: Ferulic acid, TKR: Tyrosine kinase receptor

Table 4. The rerank score, type of bonding interactions, and amino acids involved in the interaction of ligands with TKR (PDB 1XKK)

\begin{tabular}{llllll} 
Compound & $\begin{array}{l}\text { Rerank score (kcal/ } \\
\text { mol) }\end{array}$ & $\begin{array}{l}\text { Number of } \\
\text { H-bonds }\end{array}$ & $\begin{array}{l}\text { Amino acid } \\
\text { residue }\end{array}$ & $\begin{array}{l}\text { Number of } \\
\text { steric } \\
\text { interactions }\end{array}$ & Amino acid residue \\
\hline FA & -84.954 & 1 & Lys745 & 9 & $\begin{array}{l}\text { Ala743, Gly796, Leu792, Leu844, Lys745, } \\
\text { Met793, Val726 }\end{array}$ \\
\hline Celecoxib & -93.163 & 2 & Met793 & 24 & $\begin{array}{l}\text { Ala743, Asp855, Gln791, Leu792, Leu844, } \\
\text { Lys745, Met793 }\end{array}$ \\
\hline
\end{tabular}


Table 5. The rerank score, type of bonding interactions, and amino acids involved in the interaction of ligands with COX-2 (PDB 1CX2)

\begin{tabular}{|c|c|c|c|c|c|}
\hline Compound & $\begin{array}{l}\text { Rerank score } \\
(\mathrm{kcal} / \mathrm{mol})\end{array}$ & $\begin{array}{l}\text { Number of } \\
\mathrm{H} \text {-bonds }\end{array}$ & Amino acid residue & $\begin{array}{l}\text { Number of } \\
\text { steric interactions }\end{array}$ & Amino acid residue \\
\hline FA & -73.416 & 3 & Ser353, His 90 & 3 & Tyr355, Val523, Leu352 \\
\hline
\end{tabular}

COX-2: Cyclooxygenase-2, FA: Ferulic acid, Ser: Serine, Arg: Arginine, His: Histidine, Leu: Leucine, Glt: Glutamine, Tyr: Tyrosine, Phe: Phenylalanine, Val: Valine

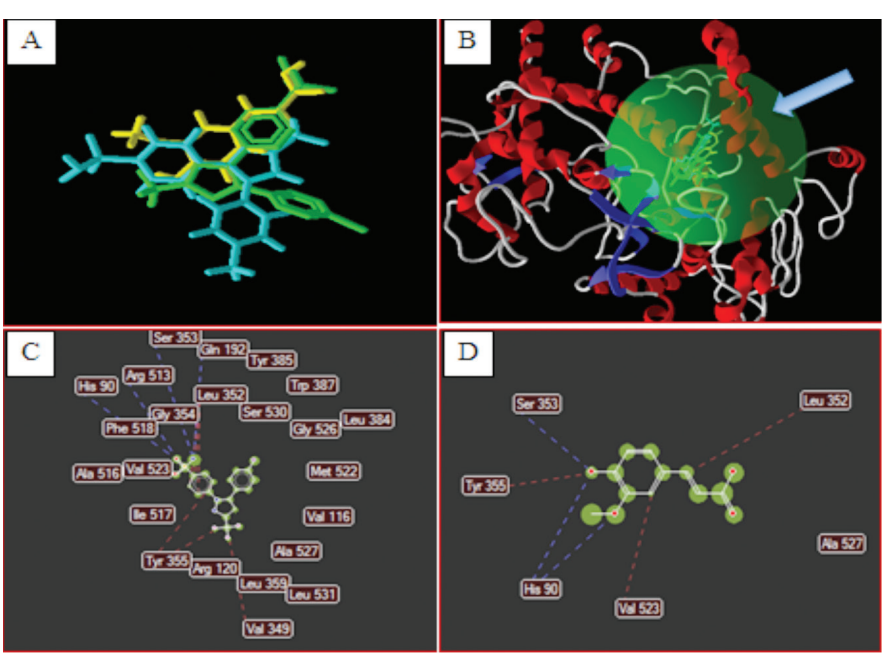

Figure 7. The best docking of FA (yellow)-celecoxib (blue)-SC58 (green) A); the three ligands positioned at the active site (cavity-3) of COX-2 B); the interaction of celecoxib with amino acids COX-2 C); interaction of FA with amino acids COX-2 D), PDB 1CX2

FA: Ferulic acid, COX-2: Cyclooxygenase-2

There are several phases of angiogenesis inhibition, i.e. prevention of endogenous angiogenic factors such as bFGF and VEGF; inhibition of the degradation matrix metalloproteinase (MMP), reducing endothelial cell proliferation; and prevention of endothelial cell movement, inhibiting endothelial cell activation and differentiation. ${ }^{33}$

Based on the data and description above, the mechanisms by which FA prevents angiogenesis are by blocking COX-2 activity so that MMP activity, which plays a role in the early formation of branching of blood vessels, will stop, and by obstructing endogenous angiogenic factors, i.e. VEGF and bFGF, in the initial stage of angiogenesis.

\section{Study limitations}

In our study, FA inhibits angiogenesis in the CAM model in the earliest process, i.e. endogenous angiogenic factors and kinase activity promoting release of growth signals. Thus, the potency of FA to inhibit angiogenesis at other stages needs further research.

\section{CONCLUSION}

FA (at a dose of $30-90 \mu \mathrm{g}$ ) is a promising antiangiogenic therapeutic agent, especially in an early stage of angiogenesis. It prevents proangiogenic growth factor, which leads to inflammation (i.e. bFGF), activity of MMP, and development of branching of blood vessels. This activity results from inhibitory action on COX-2 and VEGF-2 proteins.

Conflicts of interest: All authors declare that they have no competing interests.

Financial Disclosure: Publication of this article was funded by PTUPT Grant Airlangga University 2017/2018.

\section{REFERENCES}

1. Roskoski R. Sunitinib: A VEGF and PDGF receptor protein kinase and angiogenesis inhibitor. Biochem Biophys Res Commun. 2007;356:323328.

2. Sahin $M$, Sahin E, Gümüslü S. Cyclooxygenase-2 in cancer and angiogenesis. Angiology. 2015;60:242-253.

3. Bikfalvi A, Moenner M, Javerzat S, North S, Hagedorn M. Inhibition of angiogenesis and the angiogenesis/invasion shift. Biochem Soc Trans. 2011;39:1560-1564.

4. Saha S, Islam MK, Shilpi JA, Hasan S. Inhibition of VEGF: a novel mechanism to control angiogenesis by Withania som-nifera's key metabolite Withaferin A. In Silico Pharmacol. 2013;1:11.

5. Taylor M, Coleman RL, Sood AK. The Role of Angiogenesis in Cancer. Target Ther Transl Cancer Res. 2015:64-71.

6. Newton HB. Bevacizumab: Review of Development, Pharmacology, and Appli-cation to Brain Tumors. Clin Med Ther. 2009;1:1577-1597.

7. Gotink KJ, Verheul HMW. Anti-angiogenic tyrosine kinase inhibitors: what is their mechanism of action? Angiogenesis. 2010;13:1-14.

8. Altun A, Temiz TK, Balcı E, Polat ZA, Turan M. Effects of tyrosine kinase inhibitor E7080 and eNOS inhibitor L-NIO on colorectal cancer alone and in combination. Chin J Cancer Res. 2013;25:572-584.

9. Graf E. Antioxidant potential of ferulic acid. Free Radic Biol Med. 1992;13:435-448.

10. Itagaki S, Kurokawa T, Nakata C, Saito Y, Oikawa S, Kobayashi M, Hirano $\mathrm{T}$, Iseki K. In vitro and in vivo antioxidant properties of ferulic acid: A comparative study with other natural oxidation inhibitors. Food Chem. 2009;114:466-471.

11. Peng CC, Chyau CC, Wang HE, Chang CH, Chen KC, Chou KY, Peng RY. Cytotoxicity of ferulic acid on T24 cell line differentiated by different microenvironments. Biomed Res Int. 2013;2013:579859.

12. Senawong T, Khaopha S, Misuna S, Komaikul J, Senawong G, Wongphakham P, Yunchalard S. Phenolic acid composition and anticancer activity against human cancer cell lines of the commercially available fermentation products of Houttuynia cordata. Science Asia. 2014:40:420-427. 
13. Wang L, Chen W, Xie X, He Y, Bai X. Celecoxib Inhibits Tumor Growth and Angiogenesis in an Orthotopic Implantation Tumor Model of Human. Exp Oncol. 2008;30:42-51.

14. Nile SH, Ko EY, Kim DH, Keum YS. Screening of ferulic acid related compounds as inhibitors of xanthine oxidase and cyclooxygenase-2 with anti-inflammatory activity. Brazilian J Pharmacogn 2016, 26:50-5. Available from: http://dx.doi.org/ 10.1016/j.bjp.2015.08.013

15. Rosas C, Sinning M, Ferreira A, Fuenzalida M, Lemus D. Celecoxib decreases growth and angiogenesis and promotes apoptosis in a tumor cell line resistant to chemotherapy. Biol Res. 2014;47:1-9.

16. Koki AT, Masferrer JL. Celecoxib: A specific COX-2 inhibitor with anticancer properties. Cancer Control. 2002;9(Suppl 2):28-35.

17. Wu GF, Luo J, Rana JS, Laham R, Sellke FW, Li J. Involvement of COX-2 in VEGF-induced angiogenesis via P38 and JNK pathways in vascular endothelial cells. Cardiovasc Res. 2006;69:512-519.

18. Ribatti $\mathrm{D}$. The chick embryo chorioallantoic membrane as an in vivo assay to study antiangiogenesis. Pharmaceuticals (Basel). 2010;3:482513.

19. Yuan YJ, Xu K, Wu W, Luo Q, Yu JL. Application of the chick embryo chorioallantoic membrane in neurosurgery disease. Int J Med Sci. 2014;11:1275-1281.

20. Ekowati J, Hardjono S, Hamid IS. Ethyl p -methoxycinnamate from Kaempferia galanga inhibits angiogenesis through tyrosine kinase. Universa Med. 2015;34:43-51.

21. Richardson M, Wong D, Lacroix S, Stanis.z J, Singh G. Inhibition by doxycycline of angiogenesis in the chicken chorioallantoic membrane (CAM). Cancer Chemother Pharmacol. 2005;56:1-9.

22. Burri PH, Hlushchuk R, Djonov V. Intussusceptive angiogenesis: Its emergen-ce, its characteristics, and its significance. Dev Dyn. 2004:231:474-488.

23. Dannenberg AJ, Lippman SM, Mann JR, Subbaramaiah K, DuBois RN. Cyclooxygenase-2 and epidermal growth factor receptor: Pharmacologic targets for chemoprevention. J Clin Oncol. 2005;23:254-266.

24. Kuwano T, Nakao S, Yamamoto H, Tsuneyoshi M, Yamamoto T, Kuwano $\mathrm{M}$, Ono M. Cyclooxygenase 2 is a key enzyme for inflammatory cytokineinduced angiogenesis. FASEB J. 2004;18:300-310.
25. Di Marco GS, Reuter S, Hillebrand U, Amler S, König M, Larger E, Oberleithner $\mathrm{H}$, Brand $\mathrm{E}$, Pavenstädt $\mathrm{H}$, Brand M. The soluble VEGF receptor sFlt1 contributes to endothelial dysfunction in CKD. J Am Soc Nephrol. 2009;20:2235-2245.

26. Hsu HH, Lin YM, Shen CY, Shibu MA, Li SY, Chang SH, Lin CC, Chen RJ, Viswanadha VP, Shih HN, Huang CY. Prostaglandin E2-Induced COX2 Expressions via EP2 and EP4 Signaling Pathways in Human LoVo Colon Cancer Cells. Int J Mol Sci. 2017;18:1132.

27. Yao L, Liu F, Hong L, Sun L, Liang S, Wu K, Fan D. The function and mechanism of COX-2 in angiogenesis of gastric cancer cells. J Exp Clin Cancer Res. 2011;30:13.

28. Klenke FM, Gebhard MM, Ewerbeck V, Abdollahi A, Huber PE, Sckell A. The selective Cox-2 inhibitor Celecoxib suppresses angiogenesis and growth of secondary bone tumors: an intravital microscopy study in mice. BMC Cancer. 2006;6:9.

29. Moschona A, Kyriakidis KD, Kleontas AD, Liakopoulou-M. Comparative Study of Natural Phenolic Acids and Flavonols as Antiplatelet and AntiInflammatory Agents. The Grant Med J. 2017;2:57-66.

30. Manoharan S, Rejitharaji T, Prabhaka MM, Manimaran A, Sing RB. : Modulating Effect of Ferulic Acid on NF-kB, COX-2 and VEGF Expression Pattern During. 7,12-Dimethylbenz(a)anthracene Induced Oral Carcinogenesis. The Open Nutraceuticals Journal. 2014;7:33-38.

31. Schmidt U, Ahmed J, Michalsky E, Hoepfner M, Preissner R. Comparative Vegf Receptor Tyrosine Kinase Modeling for the Development of Highly Specific Inhibitors of Tumor Angiogenesis. Genome Inform. 2008;20:243-251.

32. Jeltsch M, Leppanen VM, Saharinen P, Alitalo K. Receptor Tyrosine Kinase-Mediated Angiogenesis. Cold Cold Spring Harb Perspect Biol. 2013;5:a009183.

33. Stegmann TJ, Hoppert T, Schneider A, Popp M, Strupp G, Ibing RO, Hertel A. Therapeutic Angiogenesis : Intramyo-cardial Growth Factor Delivery of FGF-1 as Sole Therapy in Patients with Chronic Coronary Artery Diease:1-14. Available from: https://citeseerx.ist.psu.edu/ viewdoc/download?doi=10.1.1.577.9796\&rep=rep1\&type=pdf 